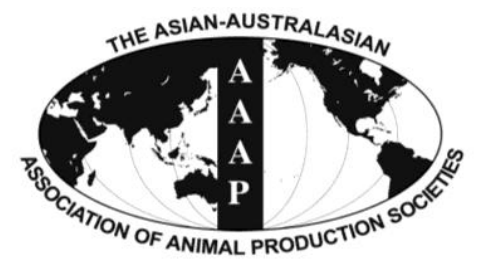

Asian-Aust. J. Anim. Sci.

Vol. 25, No. 7 : 956 - 961

July 2012

www.ajas.info

http://dx.doi.org/10.5713/ajas.2011.11482

\title{
Feed Intake, Digestibility, and N Retention in Cattle Fed Rice Straw and Para Grass Combined with Different Levels of Protein Derived from Cassava Foliage
}

\author{
K. Sath ${ }^{1,2}$, K. Sokun ${ }^{1}$, T. Pauly ${ }^{2}$ and K. Holtenius ${ }^{2, *}$ \\ ${ }^{1}$ Centre for Livestock and Agriculture Development (CelAgrid), P.O. Box 2423, Phnom Penh, Cambodia
}

\begin{abstract}
Eight male cattle of Local Yellow breed with an average live weight of $121 \mathrm{~kg}$ and an average age of 18 months were used to evaluate the effects of different levels of sun-dried cassava foliage supplementation (Manihot esculenta) on intake, digestibility and $\mathrm{N}$ retention. Rice straw ad libitum and para grass (Brachiaria mutica) at 1\% DM of BW comprised the basal diet. The study was arranged as a $4 \times 4$ double Latin square design, with cassava foliage contributing 0, 0.8, 1.6 or $2.4 \mathrm{~g} \mathrm{CP} / \mathrm{kg} \mathrm{BW}$. The cattle selected cassava leaves in preference to petioles. Petiole intake decreased from 64 to $48 \%$ of offered petioles when the cassava foliage proportion increased from the lowest to the highest level. The cattle consumed all the leaves at the two lower levels of cassava foliage inclusion and $91 \%$ at the highest level. Rice straw intake decreased significantly as the level of cassava foliage increased. Intake of DM, OM, NDF, and ADF increased significantly with increasing intake of cassava foliage. Daily DM intake per $100 \mathrm{~kg}$ BW increased from 2.7 to $3.2 \mathrm{~kg}$ with increasing cassava foliage intake. No effect on CP digestibility was detected when the level of cassava foliage increased. Digestibility of DM, OM, NDF and ADF was significantly higher in the group fed no cassava foliage than in the other groups. $\mathrm{N}$ retention increased from 16 to $28 \mathrm{~g} / \mathrm{d}$ with the first level of cassava foliage inclusion, but levelled out at the two highest levels. $\mathrm{N}$ excretion increased in both faeces and urine as a response to higher intake of cassava foliage. Maximum $\mathrm{N}$ retention occurred when $40 \%$ of total N intake came from cassava foliage (equivalent to $1.3 \mathrm{~g} \mathrm{CP} / \mathrm{kg} \mathrm{BW}$ ). (Key Words: Digestibility, Intake, Cassava Foliage, Rice Straw, Para Grass)
\end{abstract}

\section{INTRODUCTION}

In many tropical areas, cattle production depends on natural pasture and crop residues, mainly rice straw during the long dry season. These feeds have low digestibility and are usually imbalanced in essential nutrients, leading to low feed intake and poor performance (Wanapat, 1990). Supplementation of a diet based on low quality forage with small amounts of essential nutrients can improve ruminant productivity (Preston and Leng, 1987).

Cassava (Manihot esculenta) is cultivated in many regions of South East Asia, mainly for its roots. The leaves are usually left in the field, despite being a good protein source for cattle, particularly during the dry season. Thus it

\footnotetext{
* Corresponding Author: K. Holtenius. Tel: +46-18-671629, Fax: +46-18-162946, E-mail: Kjell.Holtenius@slu.se

${ }^{2}$ Department of Animal Nutrition and Management, Swedish University of Agricultural Sciences (SLU), Kungsängen Research Centre, SE 753 23, Uppsala, Sweden.

Submitted Dec. 13, 2011; Accepted Jan. 31, 2012; Revised Feb. 13, 2012
}

would be useful if farmers could use cassava leaves for cattle feed. Early work with fresh cassava foliage by Ffoulkes and Preston (1977) showed that there was no advantage from providing additional soybean meal when cassava foliage was used as the sole source of fibre and protein in a diet supplemented with molasses and 3\% urea. Under these conditions, the growth rate of fattening was almost 900 g/d. In Thailand, Wanapat et al. (1997) have drawn attention to the potential of cassava foliage preserved as hay, which combines leaves, stems and petioles as feed for ruminants, with voluntary feed intake of steers comprising up to $3.2 \%$ of BW and DM digestibility of $71 \%$ when cassava hay was fed as the sole feed. In Vietnam, Do et al. (2002) reported a curvilinear increase in nitrogen $(\mathrm{N})$ retention in goats when fresh cassava leaves replaced grass as the supplement to ammoniated rice straw. Those authors reported that the intake of urea-treated rice straw increased by $100 \%$ and total dry matter (DM) intake by $38 \%$ at the highest level of cassava foliage and that the goats showed a significant increase in digestibility of organic matter (OM), crude fibre and ash. Moreover, Khang and Wiktorsson 
(2006) reported that supplying $1 \mathrm{~g}$ crude protein (CP) per $\mathrm{kg}$ body weight (BW) as cassava foliage, either ensiled or sun-dried, before pelleting, improved the growth rate of heifers and stimulated feed intake. Sath et al. (2008) reported that the response to sun-dried cassava foliage protein in cattle fed untreated rice straw and rumen supplement was linear over the range 0 to $1.6 \mathrm{~g} \mathrm{CP} / \mathrm{kg} \mathrm{BW}$ and increased DM intake by $30 \%$ and CP intake by $65 \%$ at the highest level. The optimal level of cassava foliage supplementation to roughage diets for cattle has yet to be defined. In view of the potential of cassava foliage as a supplement for cattle, there is a need for research on this feed ingredient.

The aim of the present study was to evaluate the effects of different levels of sun-dried cassava foliage on intake, digestibility, weight gain and $\mathrm{N}$ retention in Local Yellow cattle fed rice straw and para grass as the basal diet.

\section{MATERIALS AND METHODS}

The experiment was carried out at the Centre for Livestock and Agriculture Development, about $25 \mathrm{~km}$ south of Phnom Penh, Cambodia. Mean daily temperature during the experiment ranged from $26^{\circ} \mathrm{C}$ to $32^{\circ} \mathrm{C}$. The experiment was carried out from May to July, 2009.

\section{Treatments and design}

The experiment was arranged as a $4 \times 4$ double Latin square design with periods of 15 days on each treatment, 10 days for adaptation and 5 days for data collection. All animals were fed rice straw ad libitum and para grass at $1 \%$ DM of BW as the basal diet. Only the level of cassava foliage differed between the four feed groups.

The four diets were:

$$
\begin{aligned}
\mathrm{T}_{1} & \text { : Rice straw+para grass } \\
\mathrm{T}_{2} & \text { : Rice straw+para grass } \\
& + \text { sun-dried cassava foliage }(0.8 \mathrm{~g} \mathrm{CP} / \mathrm{kg} \mathrm{BW}) \\
\mathrm{T}_{3} \text { : } & \text { Rice straw+para grass } \\
& \text { +sun-dried cassava foliage }(1.6 \mathrm{~g} \mathrm{CP} / \mathrm{kg} \mathrm{BW}) \\
\mathrm{T}_{4} \text { : } & \text { Rice straw+para grass } \\
& \text { +sun-dried cassava foliage }(2.4 \mathrm{~g} \mathrm{CP} / \mathrm{kg} \mathrm{BW})
\end{aligned}
$$

\section{Diets and feeding}

Water was available during the whole period. Rice straw was collected after harvesting rice, which was grown during the rainy season, and stored under a roof. Para grass was grown as a monoculture, collected and stored for one day prior to feeding. Cassava foliage was collected after root harvesting. The cassava leaves plus petioles were separated from the hard stems and sun-dried for 3 to 5 days by spreading them on a plastic sheet placed on the ground. After sun-drying, the foliage was stored in hay bags under a
Table 1. Chemical composition of feeds used in the experiment

\begin{tabular}{lccccc}
\hline & $\begin{array}{c}\text { Rice } \\
\text { straw }\end{array}$ & $\begin{array}{c}\text { Para } \\
\text { grass }\end{array}$ & $\begin{array}{c}\text { Cassava } \\
\text { leaves }\end{array}$ & $\begin{array}{c}\text { Cassava } \\
\text { petioles }\end{array}$ & $\begin{array}{c}\text { Whole } \\
\text { cassava } \\
\text { foliage }\end{array}$ \\
\hline $\mathrm{DM}^{1}(\%)$ & 89.5 & 19.4 & 87.9 & 88.6 & 88.8 \\
$\mathrm{In} \% \mathrm{DM}$ & & & & & \\
$\mathrm{CP}^{2}$ & 3.5 & 14.6 & 23.2 & 8.8 & 19.3 \\
$\mathrm{OM}^{3}$ & 86.6 & 87.9 & 92.3 & 91.7 & 92.1 \\
$\mathrm{NDF}^{4}$ & 74.5 & 69.1 & 55.8 & 58.8 & 57.3 \\
$\mathrm{ADF}^{5}$ & 50.3 & 45.9 & 32.4 & 49.4 & 44.6 \\
$\mathrm{Ash}^{6}$ & 13.4 & 12.1 & 7.7 & 8.3 & 7.9 \\
\hline
\end{tabular}

$\mathrm{DM}=$ Dry matter, $\mathrm{CP}=$ Crude protein, $\mathrm{OM}=$ Organic matter,

$\mathrm{NDF}=$ Neutral detergent fibre, $\mathrm{ADF}=$ Acid detergent fibre.

${ }^{1}$ Determined according to Undersander et al. (1993).

${ }^{2} \mathrm{CP}=\mathrm{N} \times 6.25, \mathrm{~N}$ determined according to AOAC (1990).

${ }^{4,5}$ According to Goering and Van Soest (1970).

3,6 Methods according to AOAC (1990).

roof. The nutrient value of the feed components is shown in Table 1.

\section{Animals and management}

Eight male cattle of the Local Yellow breed with an average BW of $121 \mathrm{~kg}$ and an average age of 18 months at the start of experiment were used. The cattle were wormed using ivermectin and vaccinated against foot-and-mouth disease prior to the experiment. They were kept in individual metabolic cages $(1 \mathrm{~m} \times 1.8 \mathrm{~m}$, with roof) allowing total collection of urine and faeces and had unlimited access to the experimental diets. Para grass and rice straw were cut to a length of about 30 to $40 \mathrm{~cm}$ before feeding. The experimental diets were fed three times a day, at 08:00, 12:00 and 16:00 in equal portions. During the trial, the cattle were weighed in the morning before feeding at the beginning and at the end of each period.

Feed refusals were collected and the DM weight was recorded each morning for individual animals. Total collection of faeces and urine was performed on a daily basis during the last 5 days of the collection period. Subsamples of faeces were taken from daily samples and stored in a freezer. The samples from each animal were pooled for each period before analysis. Urine was collected in a bucket containing $10 \mathrm{ml} 10 \%$ sulphuric acid $\left(\mathrm{H}_{2} \mathrm{SO}_{4}\right)$ to keep $\mathrm{pH}$ below 4, thus preventing escape of ammonia. Approximately $1 \%$ of total urine excreted was sampled and stored in a freezer for later analysis. Blood samples of about $10 \mathrm{ml}$ were taken from one of the jugular veins into a tube by needle on the last day of each period. Blood samples were refrigerated and then centrifuged at 3,000 (rpm) for $20 \mathrm{~min}$. The plasma was harvested after centrifugation and stored frozen until analysis.

The DM of feed and faecal samples was determined as described by Undersander et al. (1993). Ash and $\mathrm{N}$ (including urine $\mathrm{N}$ ) were determined according to AOAC 
(1990). Neutral detergent fibre (NDF) and acid detergent fibre (ADF) were determined using the procedure of Goering and Van Soest (1970). Plasma urea was analyzed by means of a commercial enzymatic kit, (Abbott Urea nitrogen B7D7F8 Abbott, Wiesbaden, Germany).

\section{Statistical analysis}

The data were analysed by analysis of variance (ANOVA) using the General Linear Model procedure of MINITAB Software, version 16.1.1 (Minitab, 2010). Treatment means which showed significant differences at the probability level of $\mathrm{p}<0.05$ were compared using Turkey's pair-wise comparison procedures. The following statistical model was used:

$$
\mathrm{y}_{\mathrm{ijkl}}=\mu+\mathrm{P}_{\mathrm{i}}+\mathrm{A}_{\mathrm{j}}+\mathrm{T}_{\mathrm{k}}+\mathrm{S}_{\mathrm{l}}+\mathrm{e}_{\mathrm{ijkl}}
$$

where: $\mathrm{y}_{\mathrm{ijkl}}=$ the dependent variable, $\mu=$ overall mean, $\mathrm{P}_{\mathrm{i}}=$ effect of period, $\mathrm{A}_{\mathrm{j}}=$ effect of animal, $\mathrm{T}_{\mathrm{k}}=$ effect of levels of cassava foliage, $S_{1}=$ effect of square and $e_{i j k l}=$ effect of random error.

\section{RESULTS}

\section{Feed intake}

The sun-dried cassava foliage was composed of $57 \%$ leaves and $43 \%$ petioles. The actual intake of cassava foliage was lower than the offered levels of 0.8, 1.6 and 2.4 $\mathrm{g} \mathrm{CP} / \mathrm{kg} \mathrm{BW}$, amounting to $0.6( \pm 0.05), 1.3( \pm 0.06)$ and 1.7 $( \pm 0.1) \mathrm{g} \mathrm{CP} / \mathrm{kg} \mathrm{BW}$, respectively, in treatments $\mathrm{T}_{2}, \mathrm{~T}_{3}$ and $\mathrm{T}_{4}$. In addition, the cattle selected cassava leaves in preference to petioles. Petiole consumption decreased gradually from $64( \pm 24.1)$ to $48( \pm 9.0) \%$ of the total amount of petioles offered when the amount of cassava foliage offered increased from 0.8 to $2.4 \mathrm{~g} \mathrm{CP} / \mathrm{kg} \mathrm{BW}$. The cattle consumed all the leaves in the $\mathrm{T}_{2}$ and $\mathrm{T}_{3}$ diets, while with the $\mathrm{T}_{4}$ diet they consumed $91 \pm 5.9 \%$ of the leaves.
Table 3. Apparent digestibility coefficients for cattle fed the four different diets $\left(\mathrm{T}_{1}\right.$ to $\left.\mathrm{T}_{4}\right)$

\begin{tabular}{|c|c|c|c|c|c|c|}
\hline & $\mathrm{T}_{1}$ & $\mathrm{~T}_{2}$ & $\mathrm{~T}_{3}$ & $\mathrm{~T}_{4}$ & $\mathrm{SE}$ & $\mathrm{p}$ \\
\hline \multicolumn{7}{|c|}{ Nutrient digestibility (\%) } \\
\hline $\mathrm{DM}$ & $63.9^{\mathrm{a}}$ & $60.5^{\mathrm{b}}$ & $60.4^{\mathrm{b}}$ & $58.5^{\mathrm{b}}$ & 0.7 & $<0.001$ \\
\hline $\mathrm{CP}$ & 60.2 & 60.2 & 60.5 & 58.6 & 1.3 & 0.725 \\
\hline $\mathrm{OM}$ & $67.4^{\mathrm{a}}$ & $63.7^{\mathrm{b}}$ & $63.1^{\mathrm{b}}$ & $60.9^{\mathrm{b}}$ & 0.7 & $<0.001$ \\
\hline $\mathrm{NDF}$ & $67.9^{\mathrm{a}}$ & $64.0^{\mathrm{b}}$ & $63.8^{\mathrm{b}}$ & $62.0^{\mathrm{b}}$ & 0.8 & $<0.001$ \\
\hline $\mathrm{ADF}$ & $65.7^{\mathrm{a}}$ & $59.2^{\mathrm{b}}$ & $60.1^{\mathrm{b}}$ & $56.6^{\mathrm{b}}$ & 1.1 & $<0.001$ \\
\hline
\end{tabular}

$\overline{a, b, c}$ Means within rows marked with different subscript letters are significantly different $(\mathrm{p}<0.05)$

$\mathrm{DM}=$ Dry matter, $\mathrm{CP}=$ Crude protein, $\mathrm{OM}=$ Organic matter, $\mathrm{NDF}=$ Neutral detergent fibre, $\mathrm{ADF}=$ Acid detergent fibre.

The sun-dried cassava foliage accounted for $0,12,21$ and $27 \%$ of the total dietary DM intake for treatments $\mathrm{T}_{1}, \mathrm{~T}_{2}$, $\mathrm{T}_{3}$ and $\mathrm{T}_{4}$, respectively (Table 2 ). No refusals were seen for para grass, which was fed at $1 \% \mathrm{DM}$ of $\mathrm{BW}$ in all treatments. However, the intake of rice straw decreased significantly with increasing cassava foliage intake. The total intake of DM, OM, NDF and ADF increased significantly with increasing intake of cassava foliage. However, intake of DM, NDF and ADF did not show any difference between the two lowest $\left(\mathrm{T}_{1}\right.$ and $\left.\mathrm{T}_{2}\right)$ and the two highest $\left(\mathrm{T}_{3}\right.$ and $\left.\mathrm{T}_{4}\right)$ levels of cassava foliage (Table 2). Moreover, there was a significant effect of cassava on DM intake and the highest intake was related to high cassava foliage intake. Daily weight gain of cattle increased from $155 \mathrm{~g}$ when no cassava foliage was fed up to $492 \mathrm{~g}$ when the highest level of cassava foliage was fed, but did not show any difference between the two diets $\mathrm{T}_{1}$ and $\mathrm{T}_{2}$ or between the two diets $\mathrm{T}_{3}$ and $\mathrm{T}_{4}$.

\section{Nutrient digestibility and $\mathbf{N}$ balance}

There was a significant effect of treatment on DM, OM, NDF and ADF digestibility, all of which decreased with increasing cassava foliage intake (Table 3). However, CP

Table 2. Mean values of feed and nutrient intake and daily weight gain of cattle fed different diets

\begin{tabular}{|c|c|c|c|c|c|c|}
\hline & $\mathrm{T}_{1}$ & $\mathrm{~T}_{2}$ & $\mathrm{~T}_{3}$ & $\mathrm{~T}_{4}$ & $\mathrm{SE}$ & $\mathrm{p}$ \\
\hline \multicolumn{7}{|l|}{ Feed intake (g DM) } \\
\hline Para grass & 1,293 & 1,304 & 1,280 & 1,253 & 20.6 & 0.350 \\
\hline Rice straw & $2,173^{\mathrm{a}}$ & $1,962^{\mathrm{ab}}$ & $1,971^{\mathrm{ab}}$ & $1,824^{\mathrm{b}}$ & 69.9 & 0.017 \\
\hline Cassava foliage & 0 & 460 & 875 & 1,149 & - & - \\
\hline Total DM & $3,466^{\mathrm{b}}$ & $3,727^{\mathrm{b}}$ & $4,125^{\mathrm{a}}$ & $4,225^{\mathrm{a}}$ & 72.4 & $<0.001$ \\
\hline \multicolumn{7}{|l|}{ Nutrient intake $(\mathrm{g} / \mathrm{d})$} \\
\hline $\mathrm{OM}$ & $3,019^{c}$ & $3,269^{b}$ & $3,636^{\mathrm{a}}$ & $3,738^{\mathrm{a}}$ & 62.9 & $<0.001$ \\
\hline NDF & $2,513^{\mathrm{b}}$ & $2,624^{\mathrm{b}}$ & $2,848^{\mathrm{a}}$ & $2,875^{\mathrm{a}}$ & 53.1 & $<0.001$ \\
\hline $\mathrm{ADF}$ & $1,687^{\mathrm{b}}$ & $1,761^{\mathrm{b}}$ & $1,907^{\mathrm{a}}$ & $1,923^{\mathrm{a}}$ & 34.8 & $<0.001$ \\
\hline Total DM (\% BW) & $2.7^{\mathrm{b}}$ & $2.8^{\mathrm{b}}$ & $3.1^{\mathrm{a}}$ & $3.2^{\mathrm{a}}$ & 0.04 & $<0.001$ \\
\hline Daily gain (g/d) & $155^{\mathrm{b}}$ & $251^{\mathrm{b}}$ & $469^{\mathrm{a}}$ & $492^{\mathrm{a}}$ & 52.2 & $<0.001$ \\
\hline
\end{tabular}

\footnotetext{
$\overline{a, b, c}$ Means within rows with different subscript letters are significantly different $(\mathrm{p}<0.05)$.
}

$\mathrm{DM}=$ Dry matter intake, $\mathrm{OM}=$ Organic matter intake, $\mathrm{NDF}=$ Neutral detergent fibre intake, $\mathrm{ADF}=$ Acid detergent fibre intake 
digestibility was not affected by treatment. DM, OM, NDF and ADF digestibility was significantly higher in the group fed no cassava foliage $\left(\mathrm{T}_{1}\right)$ than in the other groups. Among diets supplemented with cassava foliage $\left(\mathrm{T}_{2}, \mathrm{~T}_{3}, \mathrm{~T}_{4}\right)$, there was no significant difference in digestibility.

Total $\mathrm{N}$ intake increased significantly, by 28,58 and $75 \%$ with the three increasing levels of cassava foliage in comparison with the group fed no cassava foliage (Table 4). $\mathrm{N}$ excretion in both faeces and urine and plasma urea increased significantly in response to higher intake of cassava foliage. The highest $\mathrm{N}$ retention $(28 \mathrm{~g} / \mathrm{d})$ was observed for diet $\mathrm{T}_{3}$ and the lowest $(16 \mathrm{~g} / \mathrm{d})$ for diet $\mathrm{T}_{1} . \mathrm{N}$ retention showed an increase when the proportion of cassava foliage increased, which levelled out at the highest level (Table 4). Plasma urea composition increased with increasing cassava foliage (Table 4). There were no difference in plasma urea composition for $\mathrm{T}_{2}, \mathrm{~T}_{3}$ and $\mathrm{T}_{4}$ but the group fed no cassava $\left(\mathrm{T}_{1}\right)$ differed significantly with the highest level of cassava foliage $\left(\mathrm{T}_{4}\right)$.

\section{DISCUSSION}

\section{Feed characteristics and intake}

The CP content of whole sun-dried cassava foliage was within the range reported previously (Khang and Wiktorsson, 2006; Wanapat et al., 2007; Sath et al., 2008; Hue et al., 2010). However, both the NDF and ADF content were higher in this study than in those by Hue et al. (2010) and Khang and Wiktorsson (2006). This higher fibre content might be related to differences in harvesting time or the proportions of leaves, petioles and stems in the harvested forage. Our cassava leaves had three-fold higher $\mathrm{CP}$ than the petioles, confirming data reported by Borin and Frankow-Lindberg (2006) and Sath et al. (2008), and the concentration of NDF and ADF was lower in the leaves than in the petioles. This could be due to more vascularised tissue for transporting the products of photosynthesis from the leaves to the rest of the plant providing a strong connection of stem to leaves.

Although there have been several previous studies on dried cassava foliage intake, data on preferences for cassava leaves and petioles appear to be largely lacking. The cattle in the present study preferred to consume leaves rather than petioles. Similarly, a previous study showed that cattle consumed $90 \%$ of cassava leaves and $45 \%$ of petioles in diets containing sun-dried cassava foliage supplemented with untreated rice straw and rumen supplement (Sath et al., 2008). The low acceptability of the sun-dried petioles may partly be due to the low protein content together with the high fibre content, but also due to the hard texture of the petioles after sun-drying. When fed fresh cassava foliage, cattle appear to consume leaves, petioles and soft stems equally, but they tend to refuse hard stems (Sath, unpublished data).

The actual daily intake of sun-dried cassava foliage accounted for $0,0.3,0.7$ and $0.9 \mathrm{~kg} / 100 \mathrm{~kg}$ BW respectively in the four different treatments. Sun-dried cassava foliage supplementation markedly increased the total DM intake. This is in line with a study by Merkel et al. (1999) showing increased DM intake as a result of protein supplementation of diets with low roughage quality, such as rice straw and para grass. A higher intake of available CP from cassava leaves presumably supports rumen microbial activity. However, according to our results, intake of cassava at a higher level than $1.6 \mathrm{~g} \mathrm{CP} / \mathrm{kg} \mathrm{BW}$ did not give rise to any further improvement in DM intake. Different factors may have contributed to this result. The cassava foliage had high fibre content, as indicated by the NDF and ADF content, and it is thus possible that total DM intake was limited by fibre when the level of cassava foliage supplementation was high. Furthermore, the increasing cassava petiole content in the diet might have limited the intake, as discussed above. A slight concomitant reduction in rice straw intake was observed with increasing intake of cassava foliage. Voluntary DM intake is limited by high fibre content in forages fed to ruminants (Allen, 1996). The fibre (NDF) content in the diet consumed in the present study was about $70 \%$, which can be regarded as a high level. The low digestibility and protein content of rice straw presumably made the cattle select their protein feed from cassava, thus preventing maximum rice straw intake. This was possibly because the animals could adjust their intake, since rice straw was offered ad libitum and para grass was restricted to $1 \%$ of BW. In contrast, Sath et al. (2008) found no effect on rice straw intake when cattle were fed increasing amounts of cassava foliage and rumen supplement $(13 \%$

Table 4. Mean values of $\mathrm{N}$ intake, $\mathrm{N}$ retention and $\mathrm{N}$ in faeces and urine for cattle fed the four different diets $\left(\mathrm{T}_{1}\right.$ to $\left.\mathrm{T}_{4}\right)$

\begin{tabular}{lcccccc}
\hline & $\mathrm{T}_{1}$ & $\mathrm{~T}_{2}$ & $\mathrm{~T}_{3}$ & $\mathrm{~T}_{4}$ & $\mathrm{SE}$ & $\mathrm{p}$ \\
\hline N cassava foliage $(\mathrm{g} / \mathrm{d})$ & 0 & 14 & 27 & 35 & - & - \\
Total N intake $(\mathrm{g} / \mathrm{d})$ & $43^{\mathrm{d}}$ & $55^{\mathrm{c}}$ & $68^{\mathrm{b}}$ & $75^{\mathrm{a}}$ & 1.1 & $<0.001$ \\
Faeces $(\mathrm{g} / \mathrm{d})$ & $17^{\mathrm{d}}$ & $22^{\mathrm{c}}$ & $27^{\mathrm{b}}$ & $31^{\mathrm{a}}$ & 1.0 & $<0.001$ \\
Urine $(\mathrm{g} / \mathrm{d})$ & $9^{\mathrm{c}}$ & $12^{\mathrm{bc}}$ & $13^{\mathrm{b}}$ & $17^{\mathrm{a}}$ & 0.7 & $<0.001$ \\
N retention $(\mathrm{g} / \mathrm{d})$ & $16^{\mathrm{c}}$ & $21^{\mathrm{b}}$ & $28^{\mathrm{a}}$ & $27^{\mathrm{a}}$ & 1.0 & $<0.001$ \\
Plasma urea mmol/L & $2.7^{\mathrm{b}}$ & $3.4^{\mathrm{ab}}$ & $3.6^{\mathrm{ab}}$ & $3.9^{\mathrm{a}}$ & 0.26 & 0.027 \\
\hline
\end{tabular}

${ }_{\mathrm{a}, \mathrm{b}, \mathrm{c}, \mathrm{d}}$ Means within row marked with different subscript letters are significantly different $(\mathrm{p}<0.05)$. 
urea, molasses and a mineral mixture).

\section{Nutrient digestibility and $\mathbf{N}$ balance}

In the present study, cassava foliage reduced the apparent digestibility of both DM and OM and the two fibre fractions NDF and ADF. This is in agreement with previous studies showing that supplementing crossbred Holstein heifers with ensiled cassava tops reduced apparent digestibility of DM, OM, CP, NDF and ADF (Man and Wiktorsson, 2001). Furthermore, Thang et al. (2009) reported significantly lower apparent digestibility of DM, $\mathrm{OM}, \mathrm{CP}, \mathrm{NDF}$ and ADF in crossbred cattle (Local Yellow $x$ Sindhi) fed only cassava foliage compared with those fed urea-treated rice straw and a mixture of stylosanthes. All apparent digestibility values, even at the highest level of cassava foliage intake in this study, were higher than those in heifers fed cassava tops as reported by Man and Wiktorsson (2001). However, there were differences in breed of cattle and a higher percentage of foliage was used in the present study. The moderate decrease in all apparent digestibility coefficients with increasing level of cassava foliage inclusion is most likely due to the fibre fraction of the feed and anti-nutritional compounds, for instance tannins, in cassava foliage. It is reasonable to assume that the lignin content was relatively high in the cassava foliage and lignin may bind cellulose and cell wall protein in strong chemical bonds, which makes these compounds undigestible (McDonald et al., 2002). Although tannin content was not determined, it can be speculated that tannin intake increased with increased cassava foliage intake. Several recent reports show that cassava foliage contains condensed tannins and hydrogen cyanide ( $\mathrm{HCN})$, which might reduce intake (Borin et al., 2005; Khang and Wiktorsson, 2006; Thang et al., 2009; Hue et al., 2010). Tannin is resistant to attack by anaerobic bacteria, which may result in lower digestibility (McDonald et al., 2002). The total $\mathrm{N}$ intake of each group was related to total DM intake. The proportion of dietary $\mathrm{N}$ from cassava foliage was 25,40 and $47 \%$ of total $\mathrm{N}$ intake at actual intakes of 0.6 , 1.3 and $1.7 \mathrm{~g} \mathrm{CP} / \mathrm{kg} \mathrm{BW}$, respectively. $\mathrm{N}$ retention tended to respond positively to intake of cassava foliage. However, cattle offered the highest cassava amount did not respond with further increased $\mathrm{N}$ retention. This lack of positive response was reflected in increased urinary $\mathrm{N}$ excretion. These results suggest that in the present study, intake of cassava foliage at $1.7 \mathrm{~g} \mathrm{CP} / \mathrm{kg} \mathrm{BW}$ was too high and the animals were not able to benefit from it. Kaitho et al. (1998) and Groff and $\mathrm{Wu}$ (2005) showed that an increased CP level increased $\mathrm{N}$ retention, urinary $\mathrm{N}$ and faecal $\mathrm{N}$, as also found in the present study. The increase in faecal $\mathrm{N}$ excretion observed here might be explained by tannins irreversibly binding to proteins, forming indigestible complexes (Reed et al., 1990; Merkel et al., 1999). As mentioned above, urinary $\mathrm{N}$ excretion was highest in the group with the highest intake of cassava foliage. High urinary $\mathrm{N}$ reflects high protein intake and rapid ruminal digestion, resulting in ammonia production in excess of microbial needs. This excess ammonia is absorbed into the blood stream, converted to urea in the liver reflected by an increased plasma urea concentration. The surplus of nitrogen is eventually excreted in urine. The $\mathrm{N}$ retention from the three diets supplemented with cassava foliage was higher than when no cassava foliage was fed. This was presumably an effect of the higher proportion of digestible $\mathrm{CP}$ of total $\mathrm{CP}$ in diets with increasing amounts of cassava foliage.

Increasing the level of cassava foliage in the diet markedly increased the daily weight gain of the cattle, from 155 to $492 \mathrm{~g} / \mathrm{d}$. This is in line with previous results showing that the cattle improved their weight gain from 201 to 402 $\mathrm{g} / \mathrm{d}$ when intake of cassava foliage increased from 0 to 1.6 g CP/kg BW (Mom et al., 2001; Sath et al., 2008). The possibility could not be excluded that increased gut fill secondary to the increased feed consumption might have contributed to the observed weight gain. Cattle offered the highest cassava level did not respond with any statistically detectable increase in body weight. The lack of response in terms of weight gain and $\mathrm{N}$ retention at the highest cassava level offered suggests that the animals were not able to increase tissue growth at the highest $\mathrm{N}$ intake. The results indicate that the optimal intake of cassava foliage is around $0.7 \mathrm{~kg} / 100 \mathrm{~kg} \mathrm{BW}$, at least under the present circumstances. Thang et al. (2010) reported that increased energy and protein overcame the ingestion of $\mathrm{HCN}$ in cattle fed cassava foliage and improved their growth rate. Thus in the present study the lack of increase in DM intake and thus limited energy intake, together with high HCN intake, might have contributed to the lack of growth response observed at the highest cassava level.

\section{CONCLUSIONS}

Increasing the level of sun-dried cassava foliage supplementation improved total DM and $\mathrm{N}$ intake of cattle fed a basal diet of rice straw and para grass, but slightly reduced apparent digestibility of DM, OM, NDF and ADF. Maximum weight gain and $\mathrm{N}$ retention were achieved when $40 \%$ of total N intake (1.3 g CP/kg BW) came from cassava foliage, corresponding to about $0.7 \mathrm{~kg} \mathrm{DM} / 100 \mathrm{~kg} \mathrm{BW}$, while higher cassava intake did not further improve animal performance.

\section{ACKNOWLEDGEMENTS}

This study was funded by the Swedish International Development Agency for Research Cooperation with Developing Countries (Sida/SAREC), through the regional 
programme Mekong basin Agriculture Research Network (MEKARN). The authors are grateful to this programme and also thank Mr. Sokun, Mr. Borey and Miss. Mao Vouchsong for their technical assistance.

\section{REFERENCES}

Allen, M. S. 1996. Physical constraints on voluntary intake of forages by ruminants. J. Anim. Sci. 74:3063-3075.

AOAC. 1990. Official method of analysis. 15th edn, Association of Official Analytical Chemist. edition (Ed. K. Helrick). Arlington p. 1230.

Borin, K., J. E. Lindberg and R. B. Ogle. 2005. Effect of variety and preservation methods of cassava leaves on diet digestibility by indigenous and improved pigs. Anim. Sci. 80:319-324.

Borin, K. and B. E. Frankow-Lindberg. 2006. The effects of effluent from biodigesters loaded with pig or cow manures on soil fertility and forage yield of cassava grown as a perennial crop. Biol. Agric. Hortic. 24:91-104.

Do, H. Q., V. V. Son, B. P. T. Hang, V. C. Tri and T. R. Preston. 2002. Effect of supplementation of ammoniated rice straw with cassava leaves or grass on intake, digestibility and $\mathrm{N}$ retention by goats. Livest. Res. Rural. Dev. 14:1-7.

Ffoulkes, D. and T. R. Preston. 1977. Cassava or sweet potato forage as combined sources of protein and roughage in molasses based diets: effect of supplementation with soybean meal. Trop. Anim. Prod. 3:186-192.

Goering, H. and P. Van Soest. 1970. Forage fiber analysis. Agriculture hand book No.379. United State Department of Agriculture, Washington DC, USA.

Groff, E. B. and Z. Wu. 2005. Milk production and nitrogen excretion of dairy cows fed different amounts of protein and varying proportions of alfalfa and corn silage. J. Dairy Sci. 88:3619-3632.

Hue, K. T., D. T. T. Van, I. Ledin, E. Spörndly and E. Wredle. 2010. Effect of feeding fresh, wilted and sun-dried foliage from cassava (Manihot esculenta Crantz) on the performance of lambs and their intake of hydrogen cyanide. Livst. Sci. 13: 155-161.

Kaitho, R. J., N. N. Umunna, I. V. Nsahlai, S. Tamminga and J. Van Bruchem. 1998. Effect of feeding graded levels of Leucaena leucocephala, Leucaena pallida, Sesbania sesban and Chamaecytisus palmensis supplements to teff straw given to Ethiopian highland sheep. Anim. Feed Sci. Technol. 72: 355-366.

Khang, D. N. and H. Wiktorsson. 2006. Performance of growing heifers fed urea treated fresh rice straw supplemented with fresh, ensiled or pelleted cassava foliage. Livst. Sci. 102:130139.
Man, N. V. and H. Wiktorsson. 2001. Cassava tops ensiled with or without molasses as additive effects on quality, feed intake and digestibility by heifers. Asian-Aust. J. Anim. Sci. 14:624-630.

McDonald, P., R. A. Edwards, J. E. D. Greenhalgh and C. A. Morgan. 2002. Animal nutrition. 6th ed. Pearson Education Limited. ISBN 0582 419069: Printed by Ashford Colour Press Ltd., Gosport.

Merkel, R. C., K. R. Pond, J. C. Burns and D. S. Fisher. 1999. Intake, digestibility and nitrogen utilization of three tropical tree legumes, II As protein supplement. Anim. Feed Sci. Technol. 82:107-120.

Minitab. 2010. Minitab statistical software, Release 16.1.1 for Window. (Minitab Inc. State College PA, USA)

Mom, S., T. R Preston, R. A. Leng and U. Meulen. 2001. Response of young cattle fed rice straw to supplementation with cassava foliage and a single drench of cooking oil. Livest. Res. Rural. Dev. 13:1-9.

Preston, T. R. and R. A. Leng. 1987. Matching ruminant production system with available resource in the tropic and subtropics. Penambul books: armidale, P.O.Box 512, Armidale, New South Wales 2350, Australia.

Reed, J. D., H. Soller and A. Woodward. 1990. Fodder tree and straw diet for sheep: intake, growth digestibility and the effects of phenolics on nitrogen utilization. Anim. Feed Sci. Technol. 30:39-50.

Sath, K., K. Borin and T. R. Preston. 2008. Effect of levels of sundried cassava foliage on growth performance of cattle fed rice straw. Livest. Res. Rural. Dev. 20(supplement):1-12.

Thang, C. M., I. Ledin and J. Bertilsson. 2009. Effect of feeding cassava and/or Stylosanthes foliage on the performance of crossbred growing cattle. Trop. Anim. Health Prod. 42:1-11.

Thang, C. M., I. Ledin and J. Bertilsson. 2010. Effect of using cassava products to vary the level of energy and protein in the diet on growth and digestibility in cattle. Livest. Sci. 128:166172.

Undersander, D., D. R. Mertens and N. Theix. 1993. Forage analysis procedures. National Forage Testing Association, Omaha. p. 154.

Wanapat, M. 1990. Nutritional aspects of ruminant production in Southeast Asia with special reference to Thailand. Printed in Thailand by Funny Press, 549/1 Senanikom 1, Phaholyothin 32, Bangkok.

Wanapat, M., C. Promkot and S. Khampa. 2007. Supplementation of cassava hay as protein replacement for soybean meal in concentrate supplement for dairy cows. Pakistan J. Nutr. 6:6871.

Wanapat, M., O. Pimpa, A. Petlum and U. Boontao. 1997. Cassava hay: A new strategic feed for ruminants during the dry season. Livest. Res. Rural Dev. 9:1-7. 